\title{
Ewolucja w regulacji opłat za przelewy transgraniczne w Unii Europejskiej (od początku lat dziewięćdziesiątych XX wieku do wprowadzenia waluty euro)
}

\author{
Evolution in cross-border transfers fees regulation \\ in the European Union \\ (from the beginning of the nineties of XX century until the \\ implementation of euro currency)
}

mgr Piotr Gałazka

E-mail: piotr.galazka@zbp.pl

\begin{abstract}
Streszczenie
Artykuł analizuje podejście instytucji unijnych do potrzeby harmonizacji, integracji i regulacji systemów płatniczych i opłat za przelewy transgraniczne w Unii Europejskiej. Przedmiotem analiz są dokumenty publikowane przez instytucje Wspólnot Europejskich, a później Unii Europejskiej w okresie od początku lat dziewięćdziesiątych XX wieku do momentu wdrożenia waluty euro z początkiem roku 2002. Taka analiza jest tym bardziej istotna, że stanowi ona obecnie podstawy aksjologiczne do podejmowania dalszych inicjatyw legislatora europejskiego w odniesieniu do szybko rozwijającego się rynku płatności w UE. Szczególnie istotne są kwestie potrzeby zapewnienia jednolitych zasad i opłat w kontekście wdrożenia wspólnej waluty w poszczególnych państwach strefy euro i stworzenia warunków do niezaburzonego rozwoju rynku pomiędzy tymi państwami.
\end{abstract}

Słowa kluczowe: płatności, prawo bankowe, Unia Europejska, opłaty, rynek trans graniczny.

\section{Summary}

The article analyses the approach of the European Union institutions to the need to harmonize, integrate and regulate payment systems and fees for cross-border transfers in the EU. The subject of the analysis are documents published by the institutions of the European Communities and later the European Union in the period from the early nineties of the twentieth century until the implementation of the euro at the beginning of 2002. They constitute — also today — the axiological foundations of the European legislators in relation to the rapidly growing payments market in the EU. Particularly important are the issues of the need to ensure uniform rules and fees in the context of the implementation of the single currency in euro area countries and create conditions for the undisturbed development of the market between these Member States.

Key words: payments, banking law, European Union, fees, cross-border market.

JEL: G210, G280,N360, K400

str. 33-37

\section{Bibliografia}

Komisja Europejska: Discussion paper „Making payments in the Internal Market”, COM (90) 447 final of 26 September 1990. Komisja Europejska: Program pracy KE „Easier cross-border payments: breaking down the barriers”, SEC (92) 621.

Wymeersch, E. (red.). (1993). Further Perspectives in Financial Integration in Europe: Reports Presented at the Brussels Meeting of the Inter- national Faculty for Corporate Market Law and Securities Regulations, 26-30 April. Bruksela. 
Komisja Europejska: Komunikat Komisji Europejskiej do Parlamentu Europejskiego i Rady z dnia 18 września 1994 r. „Fund transfers in the EU: transparency, performance and stability”, COM (94) 436 final.

Komunikat Komisji Europejskiej z dnia 11 maja 1999 r.: Implementing the framework for financial markets: action plan, COM (1999) 232 final.

Komisja Europejska: Komunikat Komisji Europejskiej do Rady i Parlamentu Europejskiego z dnia 31 stycznia 2000 r.: „Retail payments in the internal market”, COM (2000) 36 final.

Komisja Europejska: Komunikat Komisji Europejskiej do Rady, Parlamentu Europejskiego, Komitetu Ekonomiczno-Społecznego, Komitetu Regionów i Europejskiego Banku Centralnego z dnia 3 kwietnia 2001 r.: „Report on the preparations for the introduction of euro notes and co- ins", COM (2001) 190 final.

Komisja Europejska: Proposal for a Regulation of the European Parliament and of the Council on cross-border payments in euro, COM/2001/0439 final - COD 2001/0174, Dz. U. C 270 E z 25.09.2001 r., str. 270-272

Parlament Europejski: European Parliament resolution on the Commission communication to the Council and the European Parliament on Re- tail Payments in the Single Market (COM (2000) 36 - C5-0103/2000-2000/2018 (COS), 26 października $2000 \mathrm{r}$.

\section{Akty prawne}

Rozporządzenie (WE) nr 2560/2001 Parlamentu Europejskiego i Rady z dnia 19 grudnia 2001 r. w sprawie płatności transgranicznych w euro, Dz. U. UE L 344 z 28.12.2001 r., s. 13-16, polskie wydanie specjalne: Rozdział 06 Tom 004 s. $283-$ 286.

Dyrektywa (WE) nr 97/5/WE Parlamentu Europejskiego i Rady w sprawie transgranicznych przelewów bankowych, Dz. U. UE L 043 z dnia 14.02.1997 r., s. 25-30. 